\title{
Characterisation of human articular cartilage link proteins from normal and osteoarthritic cartilage
}

\author{
JUNNOSUKE RYU, CHRISTINE A. TOWLE, AND BENJAMIN \\ V. TRE A D WELL
}

From the Orthopaedic Research Laboratories, Massachusetts General Hospital and Harvard Medical School, Boston, MA 02114, USA

SUMMARY Proteoglycan link proteins were isolated from human articular cartilage obtained from normal and osteoarthritic femoral heads and purified to homogeneity employing a method previously described by this laboratory. The link proteins were analysed for amino acid composition, molecular weight on sodium dodecyl sulphate polyacrylamide gels, and ability to stabilise proteoglycan aggregates. The results of these studies were compared with those obtained with bovine link proteins. Two link proteins were identified in the purified fraction from normal and osteoarthritic human cartilage with apparent molecular weights of 54000 (link 1) and 48000 (link 2). Functionally the link proteins, isolated from osteoarthritic and normal cartilage, were indistinguishable as measured by their ability to stabilise aggregate. The amino acid compositions of normal and osteoarthritic link proteins were also found to be similar to each other but significantly different from the amino acid composition reported for the bovine link proteins. The quantities of these proteins in extracts from normal and diseased tissue were similar, as was the ratio of link protein 1 to link protein 2 .

Articular cartilage contains few cells and an abundance of surrounding extracellular matrix, consisting mainly of collagen and proteoglycans. The elasticity of cartilage is largely related to the content and the structure of the proteoglycans in the matrix. Proteoglycan aggregate, a structural unit of cartilage, is composed of proteoglycans, hyaluronic acid, and 2 link proteins which differ in molecular weight and chemical composition. The relationship between proteoglycan aggregation and cartilage structure and function is not clearly understood.

The link proteins are believed to stabilise the binding of proteoglycan monomer to hyaluronate. Although the interaction between subunit and hyaluronic acid can occur independently, stability of the aggregate to alteration in ionic concentration, $\mathrm{pH}$, centrifugal pressure, and temperature is enhanced by the presence of link proteins. ${ }^{12}$ In all hyaline cartilage studied with the exception of rat chondrosarcoma ${ }^{3}$ and fetal cartilage ${ }^{4} 2$ link proteins have been reported. The relative amounts of each of these 2 proteins (molecular weight 45-54 000 (link 1 ), and 40-48 000 (link 2)) are different depending

Accepted for publication 1 April 1981.

Correspondence to Dr Benjamin V. Treadwell. on the source of cartilage. The importance of this ratio or in fact of link 2 is not known. There is evidence that this lower molecular weight species is derived from link $1 .^{56}$

Osteoarthritis is a progressively destructive disease of the articular surfaces of joints. It is characterised by localised erosion of the cartilage surface and is accompanied by a variety of biochemical and metabolic changes. An example of a biochemical change reported by several laboratories is the decreased capacity of extracted proteoglycan from osteoarthritic cartilage to interact with hyaluronic acid to form aggregate. ${ }^{7-9}$ Palmoski and Brandt ${ }^{10}$ examined the ability of proteoglycans from hip cartilage of patients with osteoarthritis to bind to hyaluronic acid. Their results suggested that progressive morphological changes found in osteoarthritic tissue are associated with progressive defects in proteoglycan aggregation, owing at least in part to impaired ability of the proteoglycans to interact with hyaluronic acid. However, more recent work by Brandt et al. ${ }^{11}$ showed that the hyaluronate binding region of proteoglycans isolated from bovine normal and osteoarthritic cartilage to be functionally intact. They suggested that diminished aggregation of proteoglycans in osteoarthritic cartilage may be due to an abnormality in 
some other constituent of the aggregate. It was this impairment which stimulated this study to determine if there was any structural, functional, or quantitative change in the link proteins in osteoarthritic cartilage.

\section{Materials and methods}

The 2 groups of patients in this series included 5 women (average age 65.2 years, age range from 53 to 74) with osteoarthritis of the hip (as diagnosed by roentgengram and histological section), ${ }^{12}$ and the normal group consisted of 2 women and 1 man (average age 68 years, age range from 53 to 74) who had replacement of a normal femoral head with an end prosthesis after fracture of the neck of the femur. All osteoarthritic femoral heads, obtained at the time of total hip replacement, had partial areas of cartilage loss, denudation down to sclerotic bone, and localised osteophyte formation in marginal areas. Therefore sampling was obtained from less involved areas, and special care was taken to exclude osteophytic newly formed repair tissue or fibrocartilage and to avoid resecting underlying bone. All material was obtained in the fresh state at the time of resection of the femoral head. Resected femoral heads were stored at $-40^{\circ} \mathrm{C}$ until ready to use.

\section{ISOLATION OF LINK}

The procedure used was as described by Amadio et al. ${ }^{13}$ with some modification. All procedures were carried out at $4^{\circ} \mathrm{C}$ unless otherwise stated. Normal and osteoarthritic human articular cartilage was resected and minced into $1-2 \mathrm{~mm}$ size pieces. Total resected wet weight of each cartilage type was $11 \cdot 3 \mathrm{~g}$ from the normal femoral heads and $12.3 \mathrm{~g}$ from the osteoarthritic femoral heads. The cartilage was extracted by continuous stirring in $250 \mathrm{ml}$ of a solution containing $6 \mathrm{M}$ guadinium chloride $(\mathrm{GdmCl}), 75$

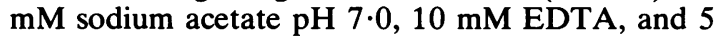
$\mathrm{mM}$ benzamidine for 72 hours. The nonsolubilised cartilage was separated from the solution by passage through 2 layers of cheese cloth. The solution was further clarified by centrifugation at $15000 \mathrm{~g}$ for 20 min.

The clear, viscous supernatant was centrifuged at $100000 \mathrm{~g}$ for 17 hours. The upper $2 / 3 \mathrm{rds}$ of the supernatant was removed and dialysed overnight against buffer $\mathrm{A}: 1 \cdot 0 \mathrm{M} \mathrm{NaCl}, 20 \mathrm{mM}$ TrisCl $\mathrm{pH} 7 \cdot 5$. The protein in the solution was precipitated by the addition of ammonium sulphate to $80 \%$ saturation adjusted to $\mathrm{pH} 3.8$ with concentrated $\mathrm{HCl}$ and collected by centrifugation at $15000 \mathrm{~g}$ for $15 \mathrm{~min}$. The precipitate was dissolved in Buffer $A$ and dialysed overnight against the buffer. $1 \mathrm{mg}$ of high molecular weight hyaluronic acid was then added to the dialysed extract for each $25 \mathrm{mg}$ of protein. The solution was dialysed for 3 hours against buffer B: $4 \mathrm{M} \mathrm{GdmCl}, 20$

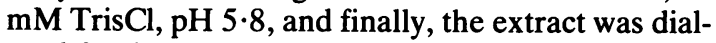
ysed for 2 hours against $0.5 \mathrm{M}$ sodium acetate, $\mathrm{pH}$ $7 \cdot 0.8 \mathrm{ml}$ aliquots of this solution were passed over a column of CL-Sepharose $6 \mathrm{~B}$ equilibrated with $0.5 \mathrm{M}$ sodium acetate, $\mathrm{pH} 7 \cdot 0$, and eluted with this buffer $(2.6 \times 35 \mathrm{~cm}$, flow rate $15-20 \mathrm{ml} /$ hour $)$. Protein containing fractions eluting in the void volume were pooled and dialysed against buffer B containing 50\% glycerol. The dialysed solution $(4-5 \mathrm{ml})$ was applied to a Sephacryl S-200 column $(2.6 \times 43 \mathrm{~cm}$, flow rate $6 \mathrm{ml} /$ hour) which had been equilibrated and eluted with buffer B. Protein containing fractions from the included volume just beyond the excluded peak were pooled, dialysed against Buffer $\mathrm{A}$ in $50 \%$ glycerol, and stored at $-20^{\circ} \mathrm{C}$ until ready to use. Further purification of the link preparation by refiltration on the Sephacryl column was only occasionally necessary. The preparation was usually more than $90 \%$ pure (Table 1).

AMINO ACID ANALYSIS OF LINK PROTEIN Samples for amino acid analysis were hydrolysed in $\mathrm{HCl}$ for 6 hours at $110^{\circ} \mathrm{C}$ in vacuo before application to a Durham Amino Acid Analyzer.

\section{SODIUM DODECYL SULPHATE}

POLYACRYLAMIDE GEL ELECTROPHORESIS OF PURIFIED LINK

Gel electrophoresis was performed according to the procedure of Weber and Osborn ${ }^{14}$ in the presence of sodium dodecyl sulphate, with $7 \cdot 5 \%$ polyacrylamide gels. Samples containing $10 \mu \mathrm{g}$ of protein were dialysed against a buffer containing $1 \% 2$-mercaptoethanol, $10 \mathrm{mM}$ sodium phosphate $\mathrm{pH} 7 \cdot 0$, and $50 \%$ glycerol for 4 hours at $37^{\circ} \mathrm{C}$ prior to electrophoresis, which was carried out at room temperature for 4 hours at a constant current of $6 \mathrm{~mA} / \mathrm{gel}$. Molecular weight standards were procollagen $(140000)$, albumin (68 000), ovalbumin (45 000), and myoglobin (17 800).

GEL FILTRATION OF PROTEOGLYCAN AGGREGATES

Bovine proteoglycan subunit (fraction A1D1) was

Table 1 Purification of link proteins from normal and osteoarthritic femoral heads

\begin{tabular}{lcc}
\hline & $\begin{array}{l}\text { Normal } \\
\text { (3 heads) }\end{array}$ & $\begin{array}{l}\text { Osteoarthritic } \\
\text { (5 heads) }\end{array}$ \\
\hline Total resected cartilage (wet wt.) & $11.3 \mathrm{~g}$ & $12.3 \mathrm{~g}$ \\
GdmCl extracted protein & $200 \mathrm{mg}$ & $400 \mathrm{mg}$ \\
$\begin{array}{l}\text { Protein in upper 2/3rds of centrifuge tube } \\
\text { (after dialysis) }\end{array}$ & $119 \mathrm{mg}$ & $153 \mathrm{mg}$ \\
Protein in (NH4),SO, precipitate & $60 \mathrm{mg}$ & $42 \mathrm{mg}$ \\
Protein in excluded peak of 6B column & $9.2 \mathrm{mg}$ & $16 \mathrm{mg}$ \\
Link protein after S-200 column & $0.4 \mathrm{mg}$ & $0.4 \mathrm{mg}$ \\
\hline
\end{tabular}


prepared by the procedure described by Heinegard. ${ }^{15}$ Purified AlDl was lyophylised and stored at $-20^{\circ} \mathrm{C}$ until ready to use.

Samples in a final volume of $0.5 \mathrm{ml}$ contained the following components: (1) $500 \mu \mathrm{g} \mathrm{AlDl}$; (2) $500 \mu \mathrm{g}$ AlDl with $6 \mu \mathrm{g}$ of high molecular weight hyaluronic acid; (3) $500 \mu \mathrm{g}$ AlDl with $6 \mu \mathrm{g}$ of high molecular weight hyaluronic acid; and $40 \mu \mathrm{g}$ of either normal or osteoarthritic articular link protein. Each sample was prepared in buffer $A$ and dialysed against buffer $B$ for 6 hours to dissociate the elements of the sample and then reassociated by dialysis against several change of $0.5 \mathrm{M}$ sodium acetate buffer at either $\mathrm{pH} 7 \cdot 0$ or $\mathrm{pH}$ 4.0 and then applied to a column of CL-Sepharose 2 B $(1 \times 22 \mathrm{~cm}$, flow rate $18 \mathrm{ml} /$ hour $)$ equilibrated and eluted with $0.5 \mathrm{M}$ sodium acetate buffer at either $\mathrm{pH} 7.0$ or $\mathrm{pH} 4.0$, An automated carbazol method for uronic acid determination ${ }^{16}$ was used to detect the elution pattern of the proteoglycan under the various $\mathrm{pH}$ conditions.

\section{Results and discussion}

This work describes the isolation, purification, and characterisation of human articular cartilage link proteins purified from human normal and osteoarthritic femoral heads. The purification procedure yields link preparations from both tissue types consisting of 2 proteins, link 1 and 2 . These 2 proteins migrated on $7.5 \%$ SDS polyacrylamide gels as species with apparent molecular weight of 54000 (link 1) and 47500 (link 2) (Fig. 1). The purified link proteins from normal and diseased tissue had similar ratios of link 1 to link 2 (1:1), as is apparent from Fig. 1. This is in contrast to the $2: 1$ ratio obtained with link preparations isolated from calf articular cartilage and bovine nasal septum. ${ }^{17}$ The apparent molecular weight of human and bovine link proteins, however, are identical as is evident from the figure showing the 2 comigrating on SDS gels.

The amino acid compositions of these proteins is essentially the same for osteoarthritic and normal human articular preparations (Table 2), though very different from those reported for the bovine preparations. ${ }^{17}$ One striking difference is the presence of 6 methionine residues in human as compared to only 2 in the bovine links. It will be interesting to determine the number of cleavage products produced by cyanogen bromide treatment of the human link proteins.

A method to measure link protein's ability to stabilise aggregate has been reported ${ }^{2}$ and was used here to assay for this activity in preparations of normal and osteoarthritic link proteins. The results of this assay (Fig. 2) demonstrate the ability of either

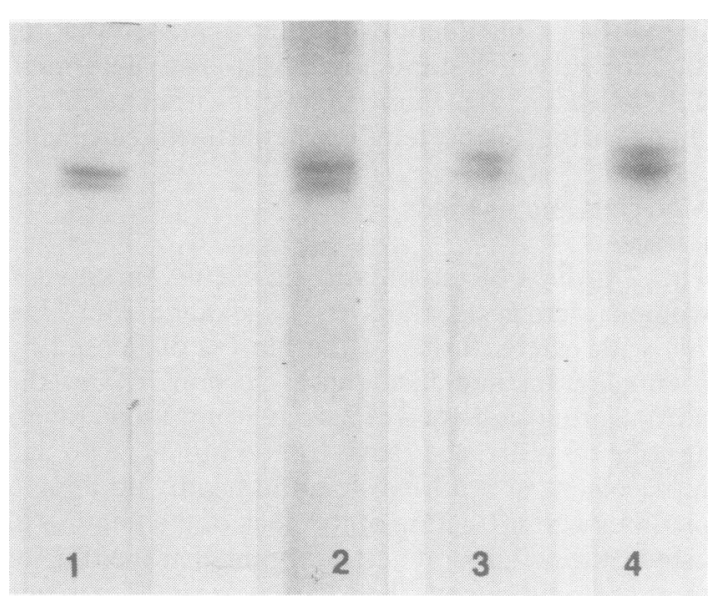

Fig. 1 Sodium dodecyl sulphate polyacrylamide gel electrophoresis of link proteins. Link proteins $(8-10 \mu \mathrm{g})$ were subjected to electrophoresis in $7.5 \%$ polyacrylamide gels in sodium dodecyl sulphate and stained with Coomassie blue. Link fractions run on individual gels were as follows: (1) 10 $\mu \mathrm{g}$ of calf articular cartilage link; (2) $8 \mu \mathrm{g}$ of normal human articular cartilage link; (3) $8 \mu \mathrm{g}$ of osteoarthritic human articular cartilage link; (4) $3 \mu \mathrm{g}$ each of normal and osteoarthritic human articular cartilage link and bovine link.

preparation to stabilise the proteoglycan hyaluronic acid interaction at $\mathrm{pH} 4 \cdot 0$. Although not shown, this assay was performed with several lower concentrations of link proteins, and the results again showed no significant difference in aggregate stabilising activity between link preparations.

The link purification scheme given in Table 1 shows that the quantity of link purified from either source was nearly identical. As is also evident from the table, there is nearly twice as much protein

Table 2 Amino acid analysis of purified link fractions

\begin{tabular}{lccc}
\hline Amino acid & $\begin{array}{l}\text { Human } \\
\text { articular link } \\
\text { (normal) }\end{array}$ & $\begin{array}{l}\text { Human } \\
\text { articular link } \\
\text { (osteoarthritic) }\end{array}$ & $\begin{array}{l}\text { Bovine } \\
\text { articular link }\end{array}$ \\
\cline { 2 - 4 } & & Residues/1000 & residues \\
\hline Aspartic acid & 105 & 107 & 127 \\
Threonine & 61 & 60 & 45 \\
Serine & 74 & 74 & 52 \\
Glutamic acid & 101 & 97 & 82 \\
Proline & 61 & 67 & 48 \\
Glycine & 98 & 90 & 99 \\
Alanine & 87 & 78 & 77 \\
Valine & 57 & 67 & 73 \\
Methionine & 7 & 6 & 2 \\
Isoleucine & 40 & 36 & 33 \\
Leucine & 90 & 103 & 86 \\
Tyrosine & 42 & 32 & 62 \\
Phenylalanine & 46 & 46 & 58 \\
Histidine & 30 & 37 & 24 \\
Lysine & 42 & 49 & 58 \\
Arginine & 60 & 51 & 72 \\
\hline
\end{tabular}




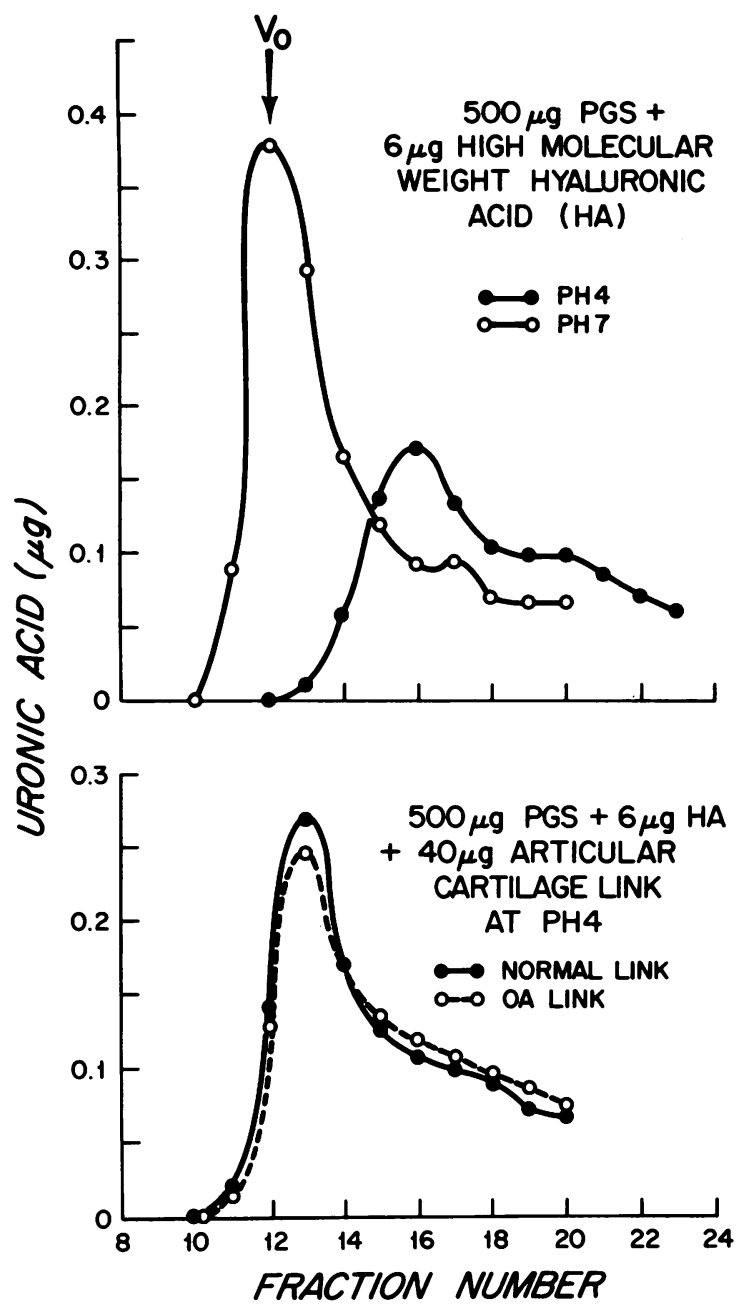

Fig. $2 C L$-Sepharose $2 B$ filtration of proteoglycan aggregates.

present in the initial osteoarthritic cartilage extract. This result is not surprising in view of reports from other laboratories showing the greater extractability of proteoglycans from osteoarthritic cartilage. ${ }^{7}$ That link protein is not also present in increased quantities is interesting and may mean that this protein is either more extractable than cartilage proteoglycans or more susceptible to degradation in the osteoarthritic extract. There have been reports of an increase level of proteolytic enzymes ${ }^{18}$ in extracts of osteoarthritic cartilage, which could account for degradation of link.

The purpose of this study was to establish whether the observed decrease in proteoglycan aggregate formation observed with extracts isolated from osteoarthritic cartilage was a result of a qualitative and/or quantitative change in the link protein. The results presented here suggest that these proteins isolated from osteoarthritic cartilage have similar functional and physical properties to link protein from normal articular cartilage. In addition the amounts of link protein extractable from normal and diseased cartilage are nearly identical.

\section{References}

Tang L H, Rosenberg L, Reiner A, Poole A R. Proteoglycans from bovine nasal cartilage: properties of a soluble form of link protein. J Biol Chem 1979; 254: 10523-31.

2 Hardingham T E. The role of link-protein in the structure of cartilage proteoglycan aggregates. Biochem $J$ 1979; 177: 237-47.

${ }^{3}$ Oegema T R, Brown M, Dziewiatkowski D D. The link protein in proteoglycan aggregates from the swarm rat chondrosarcoma. $J$ Biol Chem 1977; 252: 6470-7.

4 Vasan N S, Lash J W. Heterogeneity of proteoglycans in developing chick limb cartilage. Biochem J 1977; 164: 179-83.

5 Hascal V C. Interaction of cartilage proteoglycans with hyaluronic acid. J Supramol Struct 1977; 7: 101-20.

6 Perin J P, Bonnet F, Pizon V, Jolles J, Jolles P. Structural data concerning the link proteins from bovine nasal cartilage proteoglycan complex. FEBS Lett 1980; 119: 333-6.

7 Brandt K D. Enhanced extractability of articular cartilage proteoglycans in osteoarthrosis. Biochem J 1974; 143: 475-8.

${ }^{8}$ Moskowitz R W, Howell D S, Goldberg V M, Muniz O, Pita J C. Cartilage proteoglycan alterations in an experimentally indiced model of rabbit osteoarthritis. Arthritis Rheum 1979; 22: 155-63.

9 Vasan N. Proteoglycans in normal and severely osteoarthritic human cartilage. Biochem $J$ 1980; 187: 781-7.

${ }^{10}$ Palmoski M, Brandt K. Hyaluronate-binding by proteoglycans: comparison of mildly and severely osteoarthritic regions of human femoral cartilage. Clin Chim Acta 1976; 70: 87-95.

11 Brandt K D, Palmoski M J, Perricone E. Aggregation of cartilage proteoglycans:II. Evidence for the presence of a hyaluronatebinding region on proteoglycans from osteoarthritic cartilage. Arthritis Rheum 1976; 19: 1308-14.

12 Mankin H J, Dorfman H, Lippiello L, Zarins A. Biochemical and metabolic abnormalities in articular cartilage from osteo-arthritic human hips: II. Correlation of morphology with biochemical and metabolic data. J Bone Joint Surg 1971; 53A: 523-37.

13 Amadio P C, Treadwell B V, Towle C A, Mankin H J. Characterization of the link protein from bovine epiphyseal plate. Biochem Biophys Res Com 1980; 95: 1695-702.

${ }_{14}$ Weber K, Osborn M. The reliability of molecular weight determinations by dodecyl sulfate-polyacrylamide gel electrophoresis. J Biol Chem 1969; 244: 4406-12.

15 Heinegard D. Extraction, fractionation and characterization of proteoglycans from bovine tracheal cartilage. Biochim Biophys Acta 1972; 285: 181-92.

${ }^{16}$ Bitter T, Muir H M. A modified uronic acid carbazole action. Anal Biochem 1962; 4: 330-4.

${ }_{17}$ Treadwell B V, Shader L, Towle C A, Mankin D P, Mankin H J. Purification of the link proteins from bovine articular cartilage and comparison with link proteins from nasal septum. Biochem Biophys Res Comm 1980; 94: 159-66.

${ }^{18}$ Ehrlich M G, Mankin H J, Treadwell B V. Acid Hydrolase activity in osteoarthritic and normal human cartilage.J Bone Joint Surg 1973; 55A: 1068-76. 